\title{
Prognosis of Diabetes Complications and Efficacy of Guiera Senegalensis Aqueous Leaf Extract in Streptozotocin Induced-Diabetic Rats
}

\author{
*1OSIBEMHE, M; ${ }^{2}$ BELLO, OM; ${ }^{1}$ LAWAL, N \\ ${ }^{I}$ Department of Biochemistry and Molecular Biology, ${ }^{2}$ Department of Applied Chemistry, Federal University DutsinMa, Katsina State, \\ Nigeria. *Corresponding Author Email: mosibemhe@fudutsinma.edu.ng Tel: 08063260886
}

\begin{abstract}
Diabetes epidemics pose a serious health care problems and a huge burden on the economy of both developed and developing nations. Precise prognosis and the discovery of cost effective drugs for its management would serve as catalyst to economic recovery. This study is aimed at evaluating the prognosis of diabetes complications and the efficacy of Guiera senegalensis aqueous leaf extract in streptozotocin (STZ) induced-diabetic rats. Twelve (12) adult male Wistar rats were used in this study. Diabetes was induced by administration of $60 \mathrm{mg} / \mathrm{kg}$ of streptozotocin. Diabetic rats were treated orally with the aid of a gavage $500 \mathrm{mg} / \mathrm{kg}$ of aqueous extract of Guiera senegalensis for 21 days. Fasting blood glucose and body weight were monitored at intervals of 7 days. Some antioxidant enzymes, lipid profile and indices of renal function were assayed after the $21^{\text {st }}$ day. Post administration of $60 \mathrm{mg} / \mathrm{kg}$ of STZ produced significant $(\mathrm{P}<0.05)$ increases in fasting blood glucose, total cholesterol, triglycerides, $\mathrm{Na}^{+}$, and $\mathrm{K}^{+}$levels. Body weight, catalase and HDLcholesterol levels were reduced. Related biochemical indices (superoxide dismutase, glutathione peroxidase, LDLcholesterol, urea, creatinine, $\mathrm{Cl}^{-}$and bicarbonate) were similarly modulated by STZ but the effects were not significant relative tothe normal control. Administration of extract of Guiera senegalensis reverses the effects of STZ on these parameters. Although they were not completely brought back to normal in some cases. These findings are indications that Guiera senegalensis has the capacity to attenuate some complications of diabetes mellitus and could be considered as a potent anti-diabetic plant.
\end{abstract}

DOI: https://dx.doi.org/10.4314/jasem.v22i8.30

Copyright: Copyright $\odot 2018$ Osibemhe et al. This is an open access article distributed under the Creative Commons Attribution License (CCL), which permits unrestricted use, distribution, and reproduction in any medium, provided the original work is properly cited.

Dates: Received: 06July 2018; Revised: 15 August: 2018; Accepted: 22 August 2018

Keywords: Attenuate, catalyst, epidemics, gavage, prognosis, streptozotocin.

The burden of non-communicable diseases (NCDs): is on the increase in both high- and low-income nations (Lozano et al., 2010). Of note, diabetes mellitus has drawn public attention for its increasing prevalence.The increasing global prevalence of diabetes mellitus have led to the disease being described as "one of the main threats to human health in the twenty-first century" (Tietz, 2008). The disease is recognized as an important cause of premature death and disability (WHO, 2016) due to its complications.Persisting hyperglycemia is a forerunner of the various complications (damage and failure of different organs such as heart, kidney, eyes, nerve etc) of diabetes mellitus, leading to imbalances in some biochemical indices: lipid profile, antioxidant enzymes, electrolytes etc (Irfan et al., 2015).Assessment of the levels of these biochemical indices could be used as diagnosis and prognosis of the disease.Precise prognosis and the discovery of cost effective drugs are sine qua non to effective management of the disease.Guiera senegalensis, is a popular medicinal plant grown in west Africa. It is commonly called "Sabara" among the Hausas of the northern Nigeria, where decoction of it is used to lower blood glucose. Mohammed (2013) and Salihu and Usman (2015) havereported the presence of pharmacological important phytochemical in the plant. The plant has also been reported to be harmless to the liver at low dosage (Oshobu and Geidam 2014).This study is therefore aimed at evaluating the therapeutic potential of the plant on diabetes and its resultant complications in Wistar rats.

\section{MATERIALS AND METHODS}

Sample collection: The leaves of the plant, Guiera senegalensis were procured from Runka village, in Dutsinma LGA of Katsina State. They were identified in the Herbarium unit of Biological Science Department, Ahmadu Bello University Zaria, Kaduna State, Nigeria. And the voucher number (1823) was kept in the unit.

Preparation of extract:The extraction was carried out according to the method described by Osibemhe $e t a l$. (2016) with little modifications. Gueira senegalensis leaves procured were washed and dried under shade for two weeks. They were pulverised into powder using mortar and pestle. Measured quantity of the 
powdered plant sample was macerated in distilled water for 72 hours and kept in refrigerator to avoid microbial contamination. The solution was occasionally stirred. Then it was filtered using Cheese cloth and the filtrate was re-filtered with filter paper. It was then concentrated using water bath at $50^{\circ} \mathrm{c}$. And the slurry obtained was kept in a desiccator containing desiccant (silica gel) for complete absorption of water.

Animals: Fifteen (15) male adult rats (Wistar strain) were used for this study. The rats were purchased from University of Ibadan, Oyo State. The animals were kept under standard conditions for 2 weeks to allow them to acclimatize to the new environment and were allowed free access to water and food (Vital Feeds, Bukuru, Jos, Nigeria) ad libitum. They were handled with care in accordance with the internationally accepted practices for use and care of laboratory animals as contained in US guidelines (NIH, 1992).

Streptozotocin induction: Induction of diabetes was then carried out by single intra-peritoneal injection of $60 \mathrm{mg} / \mathrm{kg}$ of streptozotocin (Sigma St Louis, M.O., USA) dissolved in $0.9 \%$ normal saline to overnight fasted rats using insulin syringe. Diabetes mellitus was confirmed after the $10^{\text {th }}$ day of streptozotocin treatment by the observation of fasting blood glucose (FBG) >300 mg/dl using Glucometer (accu-check).

Experimental design: A total of Fifteen (15) adult rats (Wistar strain) were used. The rats were randomly selected into three (3) groups of five (5) rats per group. One group served as normal control and was given distilled water, another group served as diabetic control and also received distilled water while the other group, diabetic treated, received $500 \mathrm{mg} / \mathrm{kg}$ of aqueous extract of Guiera senegalensis for a period of 21 days. Administration was carried out with the aid of a gavage. Fasting blood glucose and body weight measurements were carried out at intervals of 7days. At the end of 21day, the animals were sacrificed and blood was collected for the analyses of biochemical parameters.

Blood collection: At the end of the $21^{\text {st }}$ day, the rats were fasted overnight. Through the abdominal aorta using $5 \mathrm{ml}$ syringe, blood sample was collected into plain containers from rats under chloroform anaesthesia. The blood sample was centrifuge at 3000 rpm for 15 minutes after which the serum was kept in clean plain sample bottles for analyses of kidney function indices (urea, creatinine and some electrolytes-Sodium $\left(\mathrm{Na}^{+}\right)$, (Potassium $\left(\mathrm{k}^{+}\right)$, Chloride $\left(\mathrm{Cl}^{-}\right)$and $\mathrm{Bi}$-carbonate $\left.\left(\mathrm{HCO}_{3}^{-}\right)\right)$, Some antioxidant enzymes (Catalase (CAT), superoxide dismutase (SOD), glutathione peroxidase (GPX)) and lipid profile (Triglycerides, total cholesterol, HDLcholesterol and LDL-cholesterol).

Biochemical analysis: Fasting blood glucose was analysed using glucometer (accu-check). Lipid profile and kidney function indices were assayed using standard laboratory kits (Randox). CAT, SOD, and GPX were assayed using standard methods of Cohen et al. (1970), Misra and Fridovich (1972) and Maehly and Chance (1954) respectively.

Statistical analysis: The results are expressed as means \pm SEM of five independent determinations. The means were compared by one-way ANOVA followed by Duncan post hoc test. Value of $\mathrm{P}$ less than $5 \%(\mathrm{P}<0.05)$ was considered statistically significant.

\section{RESULTS AND DISCUSSION}

Fasting blood glucose (Table 1): A lot of reports have been documented in literature about medicinal plants with antidiabetic potential. Majority of these plants have been reported to possess bioactive compounds that affect various metabolic cascades, which in turn affects the level of blood glucose directly or indirectly (Grover and Vats, 2001).The diagnosis of diabetes mellitus depends solely on the demostration of hyperglycemia (Tietz, 2008). In this study, no significant change was observed in the fasting blood glucose concentration of the normal control rats when compared with the basal values whereas the diabetic control group demonstrated progressive significant $(\mathrm{p}<0.05)$ increases from day 1 (day treatment with plant extract commences) through 21.The diabetic treated group demonstrated progressive significant $(\mathrm{p}<0.05)$ decrease in fasting blood glucose from day 721 (Table 1). Diabetes Mellitus (DM) is a common disorder associated with increased morbidity and mortality and can be defined as a group of metabolic diseases characterized by chronic hyperglycemia due to defective insulin secretion, insulin action, or both, resulting in impaired carbohydrate, lipid, and protein metabolism (Akahet al., 2009). The observed progressive significant increases in the fasting blood glucose of diabetic control rats in this study may be a result of low levels of insulin arising from effects of streptozotocin (STZ) on the pancreas of the rats. STZ potentiate dephosphorylation of ATP which leads to the generation of superoxide anions, hydrogen peroxides and hydroxyl radicals. This result to increase intracellular peroxides in the pancreatic islets, which may induce damage due to reactive oxygen species (Lenzen et al., 1996). The observed progressive increase in fasting blood glucose of the diabetic rats treated with the leaf extract of Guiera senegalensis may be that the plant was able to ameliorate the effect of STZ on the rats, possibly due 
to the presence of bioactive compound with the capacity to scavenge free radicals. Pancreatic islet cells protection and regeneration of beta cells have been linked to the antioxidant capacity of flavonoids (Sabuet al., 2002). Mohammed (2013) has reported the presence of flavonoids in the plant.

Body weight: The results of the weekly records of body weight of the experimental rats are presented in table 2.0. Significant $(\mathrm{p}<0.05)$ increase was observed from day 1-21 and day 14-21 in normal control and diabetictreated rats respectively. The diabetic control rats showed reduction in body weight but the decrease was not significant when compared with the basal values. Decreased body weight, reduced insulin levels, hyperglycemia, etc are general characteristics of STZinduced diabetic rat (Ding et al., 2006). The observed improvement in body weight of the diabetic-treated group in this study may be that the plant extract was able to potentiate glycemic control and structural proteins synthesis (Balamurugan and Ignacimuthu, 2011).

Kidney function indices: Hyperglycaemia-induced oxidative stress in diabetes is a major cause for the development and progression of diabetic microvascular complications such as diabetic nephropathy (Kashiharaet. al., 2010). Kidneys are among the vital organs in the body, which eliminates urea, uric acid, creatinine etc., and also maintains the water balance to the optimal levels. In diabetes, the toxic concentration of blood glucose levels, damages the renal tissue, which lead to altered renal function, causing diabetic nephropathy (Aurell and Bjorck, 1992). In this study, no significant change was seen in the levels of creatinine, urea, $\mathrm{Cl}^{-}$, and $\mathrm{HCO}_{3}{ }^{-}$, in the diabetic control and diabetic-treated groups compared to the normal control group. However, $\mathrm{Na}^{+}$and $\mathrm{K}^{+}$ levels were elevated in the diabetic control group relative to normal control. But extract of Guiera senegalensis brought these values to normal level (Table 3.0). Diabetes is associated with increased volume and metabolites excretions through the kidneys, usually in excess of normal thresholds. This often results to derangement in homeostatic balance with respect to electrolytes (Carlson, 1997). Metabolic acidosis is associated with hyperkalemia because increased hydrogen ions are available for sodium exchange in the renal tubules at the expense of potassium ions and hence result in increased retention of potassium in serum. The increased $\mathrm{K}^{+}$observed in the diabetic control may be ascribed to metabolic acidosis resulting from low levels of insulin. Development of diabetes complications depends on the stage of progression of diabetes (Hira et al., 2018). The non-significant effect in the levels of creatinine, urea, $\mathrm{Cl}^{-}$, and $\mathrm{HCO}_{3}{ }^{-}$may not be unconnected with the stage of progression of the disease.

Table 1: Mean fasting blood glucose of diabetic rats administered aqueous leaf extract of Guiera senegalensis for 21 days

\begin{tabular}{llllll}
\hline \multicolumn{5}{c}{$\mathrm{mg} / \mathrm{dl}$} \\
\hline Group & Basal & Day1 & Day7 & Day14 & Day21 \\
\hline Normal Control & $79.00 \pm 8.03^{\mathrm{bc}}$ & $65.00 \pm 4.76^{\mathrm{b}}$ & $88.25 \pm 4.92^{\mathrm{c}}$ & $67.00 \pm 4.69^{\mathrm{b}}$ & $83.00 \pm 3.32^{\mathrm{c}}$ \\
Diabetes Control & $72.50 \pm 12.87^{\mathrm{a}}$ & $312.25 \pm 41.63^{\mathrm{b}}$ & $546.75 \pm 53.25^{\mathrm{c}}$ & $522.00 \pm 46.00^{\mathrm{c}}$ & $589.25 \pm 6.24^{\mathrm{c}}$ \\
Diabetes Treated & $79.25 \pm 4.09^{\mathrm{a}}$ & $597.50 \pm 2.50^{\mathrm{b}}$ & $402.50 \pm 32.12^{\mathrm{e}}$ & $342.75 \pm 32.39^{\mathrm{de}}$ & $297.75 \pm 30.77^{\mathrm{cd}}$ \\
\hline
\end{tabular}

Values are expressed as fasting blood glucose concentration and means \pm SEM of five independent determinations. Values in the same row with different superscript represent significant $(p<0.05)$ difference from basal.

Table 2: Mean body weight of diabetic rats administered aqueous leaf extract of Guiera senegalensis for 21 days

\begin{tabular}{llllll}
\hline \multirow{2}{*}{ Group } & \multicolumn{5}{c}{$(\mathrm{g})$} \\
\cline { 2 - 5 } & Basal & Day1 & Day7 & Day14 & Day21 \\
\hline Normal Control & $134.68 \pm 2.61^{\mathrm{a}}$ & $165.94 \pm 8.20^{\mathrm{b}}$ & $171.95 \pm 6.10^{\mathrm{bc}}$ & $184.97 \pm 4.41^{\mathrm{cd}}$ & $193.76 \pm 5.25^{\mathrm{d}}$ \\
Diabetes Control & $128.56 \pm 4.62^{\mathrm{ab}}$ & $132.43 \pm 5.43^{\mathrm{b}}$ & $117.44 \pm 3.56^{\mathrm{b}}$ & $119.46 \pm 1.82^{\mathrm{a}}$ & $117.73 \pm 4.53^{\mathrm{a}}$ \\
Diabetes Treated & $121.46 \pm 7.84^{\mathrm{a}}$ & $124.56 \pm 4.52^{\mathrm{a}}$ & $135.24 \pm 5.47^{\mathrm{ab}}$ & $147.57 \pm 10.91^{\mathrm{b}}$ & $158.56 \pm 16.23^{\mathrm{b}}$ \\
\hline
\end{tabular}

Values are expressed as body weight and are means \pm SEM of five independent determinations. Values in the same row with different superscript represent significant $(p<0.05)$ difference from basal.

Table 3: Mean serum concentrations of kidney function indices of diabetic rats administered aqueous leaf extract of Guiera senegalensis for

\begin{tabular}{lllllll}
\hline Group & $\begin{array}{l}\mathrm{HCO}_{3}^{-} \\
(\mathrm{mmol} / \mathrm{L})\end{array}$ & $\begin{array}{l}\mathrm{Cl}^{-} \\
(\mathrm{mEq} / \mathrm{L})\end{array}$ & $\begin{array}{l}\text { Creatinine } \\
(\mathrm{mg} / \mathrm{dl})\end{array}$ & $\mathrm{K}^{+}(\mathrm{mEq} / \mathrm{L})$ & $\mathrm{Na}^{+}(\mathrm{mEq} / \mathrm{L})$ & Urea $(\mathrm{mg} / \mathrm{dl})$ \\
\hline Normal Control & $9.26 \pm 0.08^{\mathrm{a}}$ & $74.8 \pm 0.49^{\mathrm{a}}$ & $63.65 \pm 0.26^{\mathrm{a}}$ & $3.72 \pm 0.01^{\mathrm{a}}$ & $120.60 \pm 0.38^{\mathrm{a}}$ & $9.11 \pm 0.37^{\mathrm{ab}}$ \\
Diabetes Control & $9.13 \pm 0.16^{\mathrm{a}}$ & $73.2 \pm 0.48^{\mathrm{a}}$ & $65.18 \pm 0.69^{\mathrm{a}}$ & $3.95 \pm 0.06^{\mathrm{b}}$ & $125.05 \pm 1.72^{\mathrm{b}}$ & $9.92 \pm 0.32^{\mathrm{b}}$ \\
Diabetes Treated & $9.22 \pm 0.13^{\mathrm{a}}$ & $73.1 \pm 0.72^{\mathrm{a}}$ & $64.22 \pm 0.49^{\mathrm{a}}$ & $3.74 \pm 0.04^{\mathrm{a}}$ & $120.50 \pm 0.85^{\mathrm{a}}$ & $8.84 \pm 0.15^{\mathrm{a}}$ \\
\hline
\end{tabular}

Values are expressed as concentrations of kidney function and means \pm SEM of five independent determinations. Values in the same column with different superscript represent significant $(p<0.05)$ difference from the controls (normal and diabetic control). 
Table 4: Mean plasma activities of some anti-oxidants enzymes of diabetic rats administered aqueous leaf extract of Guiera senegalensis for 21 days

\begin{tabular}{llll}
\hline \multirow{2}{*}{ Group } & \multicolumn{3}{c}{ Unit/mg proteins } \\
\cline { 2 - 4 } & SOD & CAT & GPX \\
\hline Normal Control & $3.49 \pm 0.32^{\mathrm{ab}}$ & $27.50 \pm 2.34^{\mathrm{a}}$ & $27.81 \pm 2.79^{\mathrm{a}}$ \\
Diabetes Control & $2.99 \pm 0.48^{\mathrm{a}}$ & $9.87 \pm 1.62^{\mathrm{b}}$ & $21.87 \pm 1.23^{\mathrm{a}}$ \\
Diabetes Treated & $4.41 \pm 0.02^{\mathrm{b}}$ & $49.93 \pm 3.95^{\mathrm{c}}$ & $41.10 \pm 2.91^{\mathrm{b}}$ \\
\hline
\end{tabular}

Values are expressed as anti-oxidants activity and means \pm SEM of five independent determinations. Values in the same column with different superscript represent significant $(\mathrm{p}<0.05)$ difference from the controls (normal and diabetic control)

Table 5: Mean serum concentrations of lipid profile of diabetic rats administered aqueous leaf extract of Guiera senegalensis for 21 days

\begin{tabular}{lllll}
\hline & & \multicolumn{3}{c}{$\mathrm{mg} / \mathrm{dl}$} \\
\hline Group & Total Cholesterol & Triglycerides & LDL-Cholesterol & HDL-Cholesterol \\
\hline Normal Control & $1.93 \pm 0.89^{\mathrm{a}}$ & $0.83 \pm 0.06^{\mathrm{a}}$ & $1.22 \pm 0.03^{\mathrm{a}}$ & $0.59 \pm 0.29^{\mathrm{a}}$ \\
Diabetes Control & $2.52 \pm 0.03^{\mathrm{b}}$ & $1.66 \pm 0.39^{\mathrm{b}}$ & $1.33 \pm 0.18^{\mathrm{a}}$ & $0.44 \pm 0.01^{\mathrm{b}}$ \\
Diabetes Treated & $2.14 \pm 0.05^{\mathrm{c}}$ & $1.05 \pm 0.04^{\mathrm{ab}}$ & $1.17 \pm 0.07^{\mathrm{a}}$ & $0.49 \pm 0.02^{\mathrm{b}}$ \\
\hline
\end{tabular}

Values are expressed as concentrations of lipid profile and are means \pm SEM of five independent determinations. Values in the same column with different superscript represent significant $(\mathrm{p}<0.05)$ difference from the controls (normal control and diabetic control)

Antioxidant enzymes: Decreased antioxidant enzyme levels and enhanced lipid peroxidation have been well documented in STZ-induced diabetes (Wang et al., 2010). In this study, marginal decrease in the activities of SOD and GPX and significant $(\mathrm{p}<0.05)$ decrease in CAT activity were observed in diabetic control group compared to the normal control group. Whereas the diabetic treated group exhibited significant increase in the activity of all the antioxidant enzymes assayed in relation to normal and diabetic control groups (Table 4.0). The observed reduction in antioxidant enzymes in diabetic control group in this study may be ascribed to the effects of hyperglycemia arising from STZ action. Hyperglycemia-induced superoxide overproduction inhibits glyceraldehydes 3-phosphate dehydrogenase (GAPDH) enzyme of the glycolytic pathway through the activation of poly (ADP-ribose) polymerase (PARP). This in turns results to increased levels of the glycolytic intermediates that are upstream of GAPDH. The resultant increase in intracellular glucose is reduced by aldose reductase via the polyol pathway, consuming NADPH, an important cofactor for regenerating critical intracellular antioxidants (Lee and Chung, 1999). Thus lowering the levels of intracellular antioxidant enzymes. The observed increased in the levels of the antioxidant enzymes in the diabetic-treated group may be attributed to the ability of the plant extract to lower blood glucose.

Lipid profile: With the exception of LDL-cholesterol that had no significant change in all the groups, significant $(\mathrm{p}<0.05)$ increase were observed in the levels of total cholesterol and triglyceride in diabetic control group when compared with normal control whereas HDL-cholesterol level was significantly reduced. Marginal and significant reduction of triglyceride and total cholesterol levels were respectively observed in the diabetic treated groups compared with the diabetic control group. Marginal increase was also observed in HDL-cholesterol level.
Development of diabetes complications depends on the stage of progression of diabetes (Hira et al., 2018) and therapeutic effects of medicinal plants depends also on the stage of progression of diabetes as well as duration of treatment. The marginal effects of STZ in some of the analyzed lipids in the diabetic control group and the marginal effects of the plant extract in the diabetic treated group in this study may be connected to the stage of progression of the disease and duration of treatment. Dyslipidemia is one of the major risk factors for cardiovascular disease (CVD) in diabetes mellitus (Ira, 2011). The lowering of lipids exhibited by this plant suggests that the plant may be able to prevent CVD.

Conclusion: Diabetes epidemic is on the increase and the search for newer pharmacological agents from natural products to combat this epidemic is encouraged. The findings from this study have demonstrated that leaf extract of Guiera senegalensis possesses antioxidant, lipid lowering and antidiabetic potential and may be a good candidate for diabetes management. However, further study is recommended to investigate long term effect of the plant in diabetic animals in addition to the assessment of other prognostic factors of diabetes to support findings from this study.

\section{REFERENCES}

Akah, JA; Lemji, JA; Salawa OA; Okoye TC; Offiah, NV (2009). Effects of Vernonia amygdalina on Biochemical and Haematological Parameters in Diabetic Rats. Asian J. Medicinal Sci.1 (3): 108113.

Aurell, M; Bjorck, S (1992). Determination of progressive renal disease in diabetes mellitus. Kidney Int. 41: 38-42. 
Balamurugan, R;Ignacimuthu, S (2011). Antidiabetic activity of $\gamma$-sitosterol isolated from Lippianodi flora L. in streptozotocin induced diabetic rats. Eur J Pharmacol. 5:3-9.

Carlson, GP (1997). Fluids, electrolytes and acid-base balance. In: Kaneko, JJ; Harvey, JW; Bruss, ML (eds). Clinical Biochemistry of Domestic Animals (5th edition), Academic press San Diego London, pp. 486-513.

Ding, Y; Zou, R; Judd, RL; Zhong, J (2006). Endothelin-1 receptor blockade prevented the electrophysiological dysfunction in cardiac myocytes of streptozotocin-induced diabetic rats. Endocrine. 30:121-127.

Grover, JK; Vats, V (2001) Shifting paradigm from conventional to alternate medicine. An introduction on traditional Indian medicine. Asia Pac. Biotech News, 5:28-32.

Hira, C; Manisha, P; Chua, KH; Cheah, SM; Jessmie, KJ; Liang, YE; Ahmad, A; Soohg, WK; Tan, SY; Mallikarjuna, RP; Bapi, G; Prashant, K (2018). An update on natural compounds in the remedy of diabetes mellitus: A systemic review. Journal of Traditional and Complementary Medicine. 8:361376.

Ira, JG (2011). Diabetes dyslipidemia: causes and consequences. J. Clin. Endocrinology Metabolism. 86(3):965-971.

Irfan, M; Rabia, F; Rawoof, M; Devendra, SR; Shajrul, A; Nida, H; Sabhiya, M (2015). Estimation of lipid peroxidation and lipid profile levels in Type II DiabetesMellitus patients of Kashmir valley. Int. J. Adv. Lif. Sci. 8(4): 448-455.

Kashihara, N; Haruna, Y; Kondeti, V K; Kanwar, YS (2010). "Oxidative stress in diabetic nephropathy," Current Medicinal Chemistry. 17, (34): 4256-4269.

Lee, AY; Chung, SS (1999). Contributions of polyol pathway to oxidative stress in diabetic cataract. FASEB J. 13, 23-30.

Lenzen, S; Drinkgern, J (1996).Tiedge M. Low antioxidant enzyme gene expression in pancreatic islets compared with various other mouse tissues. Free Rad Biol Med. 20: 463-6.

Maehly, AC; Chance, B (1954). "The assay of catalases and peroxidases". Methods of Biochemical Analysis. 1:357-424.

Misra, HP; Fridovich, I (1972). The role of superoxide anion in the autoxidation of epinephrine and a simple assay for superoxide dismutase. J. Biol Chem. 247(10): 3170-3175.

Mohammed, SY (2013). Quantitative phytochemical and elemental analysis of Guierasenegalensisleaf extract. Journal of Pharmacognosy and Phytotherapy. 5(12):204-207.

National Institute of Health (1992). Institutional Animal Care and use Committee Guidebook, NIH Publication. Washington, D. C: U.S. Government Printing Office. Pp 92-345.

Oshobu, MA; Geidam, MA (2014). Effects of Aqueous Ethanolic Extract of the leaves of Guierasenegalensis JF. Gmel (Combretaceae) on Liver Function in Wister Strain Albino Rats. International Journal of scientific research and management. 2 (3):611-615.

Osibemhe, M; Abdulrahman, BO;Onoagbe I. O. (2016). Acute Toxicity of Aqueous and Ethanolic Extracts of StrophanthushispidusStem Bark. International Journal of Biochemistry Research and Review. 9(1):1-5.

Sabu,MC; Smitha, K; Ramadasan, K (2002). Antidiabetic activity of green tea polyphenols and their role in reducing oxidative stress in experimental diabetes. Journal of Ethnopharmacology. 83:109116.

Salihu, SO; Usman, AA (2015). Antimicrobial and phytochemical study of the bioactive fractions of Guierasenegalensisfrom Alasan Tambuwal, Nigeria. J. Pharmacognosy and Phytochemistry. 3(6): 106-111.

Wang, X; Ye, Xl;Liu, R;Chen, H;Bai, H; Liang, X; Zhang, X; Wang, Z; Li, W; Hai, C (2010). Antioxidant activities of oleanolic acid in vitro: possible role of Nrf2 and MAP kinases. ChemicoBiological Interactions. 184(3): 328-337 